41. Roghmann MC, Qaiyumi S, Johnson JA, Schwalbe R, Morris JG. Recurrent vancomycin-resistant Enterococcus faecium bacteremia in a leukemia patient who was persistently colonized with vancomycin-resistant enterococci for two years. Clin Infect Dis 1997;24:514-515.

42. Lai KK, Fontecchio SA, Kelley AL, Melvin ZS, Baker S. The epidemiology of fecal carriage of vancomycin-resistant enterococci. Infect Control Hosp Epidemiol 1997;18:762-765.

43. Hospital Infection Control Practices Advisory Committee. Recommendations for preventing the spread of vancomycin resistance. Infect Control Hosp Epidemiol 1995;16:105-113.

44. Wells CL, Juni BA, Cameron SB, Mason KR, Dunn DL, Ferrieri P, et al. Stool carriage, clinical isolation, and mortality during an outbreak of vancomycin-resistant enterococci in hospitalized medical and/or surgical patients. Clin Infect Dis 1995;21:45-50.

45. Shay DK, Maloney SA, Montecalvo M, Banerjee S, Wormser GP, Arduino MJ, et al. Epidemiology and mortality risk of vancomycin-resistant enterococcal bloodstream infections. J Infect Dis 1995;172:993-1000.

46. Noskin GA, Stosor V, Cooper I, Peterson LR. Recovery of vancomycinresistant enterococci on fingertips and environmental surfaces. Infect Control Hosp Epidemiol 1995;16:577-581.

47. Anderson RL, Carr JH, Bond WW, Favero MS. Susceptibility of vancomycin-resistant enterococci to environmental disinfectants. Infect Control Hosp Epidemiol 1997;18:195-199.

48. Saurina G, Landmann D, Quale JM. Activity of disinfectants against vancomycin-resistant Enterococcus faecium. Infect Control Hosp Epidemiol 1997;18:345-347.

49. Bradley CR, Fraise AP. Heat and chemical resistance of enterococci. $J$ Hosp Infect 1996;34:191-196.

50. Byers KE, Durbin LJ, Simonton BM, Anglim AM, Adal KA, Farr BM. Disinfection of hospital rooms contaminated with vancomycin-resistant Enterococcus faecium. Infect Control Hosp Epidemiol 1998;19:261-264.

51. Torell E, Fredlund H, Tornquist E, Myhre EB, Sjoberg L, Sundsfjord A. Intrahospital spread of vancomycin-resistant Enterococcus faecium in Sweden. Scand J Infect Dis 1997;29:259-263.

52. McNeil MM, Solomon SL. The epidemiology of methicillin-resistant Staphylococcus aureus. Antimicrobic Newsletter 1985;2:49-56.

53. Chow JW, Kuritza A, Shlaes DM, Green M, Sahm DF, Zervos MJ. Clonal spread of vancomycin-resistant Enterococcus faecium between patients in three hospitals in two states. J Clin Microbiol 1993;31:1609-1611.

54. Tenover FC, Tokars J, Swenson J, Paul S, Spitalny K, Jarvis W. Ability of clinical laboratories to detect antimicrobial agent-resistant enterococci. $J$ Clin Microbiol 1993;31:1695-1699.

55. Webb R, Currier M, Brackin B, Nolan R, Wilson J. Capability to identify vancomycin resistant enterococci (VRE) and other emerging pathogens in clinical microbiology laboratories serving a rural state. Infect Control Hosp Epidemiol 1997;18:(suppl)P23. Abstract.

56. Swenson JM, Ferraro MJ, Sahm DF, Charache P, the National Committee for Clinical Laboratory Standards Working Group on Enterococci, Tenover FC. New vancomycin disk diffusion breakpoints for enterococci. J Clin Microbiol 1992;30:2525-2528.

57. Swenson JM, Clark NC, Ferraro MJ, Sahm DF, Doern G, Pfaller MA, et al. Development of a standardized screening method for detection of vancomycin-resistant enterococci. J Clin Microbiol 1994;32:1700-1704.

58. National Committee for Clinical Laboratory Standards. Methods for dilution antimicrobial susceptibility tests for bacteria that grow aerobically. Approved standard M7-A3. Villanova, PA: National Committee for Clinical Laboratory Standards; 1993.

59. National Committee for Clinical Laboratory Standards. Performance standards for antimicrobial disk susceptibility tests. Approved standard
M2-A5. Villanova, PA: National Committee for Clinical Laboratory Standards; 1993.

60. Ribeiro J, Chenevert C, Miller N, Boyce J. Prevalence of vancomycinresistant enterococci (VRE) among nursing home residents (NHR) admitted to a university-affiliated hospital. Infect Control Hosp Epidemiol 1997;18:(suppl)P23. Abstract.

61. Revuelta MP, Nord JA, Yarrish RL, Kislak JW, LaBombardi V. Recycling of hospital-acquired colonization with vancomycin resistant enterococci via nursing home residents. Clin Infect Dis 1995;21:730. Abstract.

62. Sargent SJ, Baselski VS, Reed LD, Wong L, Sahm DF. Simultaneous hospital and community emergence of vancomycin-resistant Enterococcus faecium. Clin Infect Dis 1995;21:729. Abstract.

63. Bates J. Epidemiology of vancomycin-resistant enterococcus in the community and the relevance of farm animals to human infection. $J$ Hosp Infect 1997;37:89-101.

64. Coque TM, Tomayko JF, Ricke SC, Okhyusen PC, Murray BE. Vancomycin-resistant enterococci from nosocomial, community, and animal sources in the United States. Antimicrob Agents Chemother 1996;40:26052609.

65. Semmelweis I. The Etiology, the Concept, and the Prophylaxis of Childbed Fever. Pest, CA: Hartlben's Verlag-Expedition; 1861. Translated by FP Murphy and republished, Classics of Medicine Library, Birmingham, AL; 1981.

66. Larson E, Kretzer EK. Compliance with handwashing and barrier precautions. J Hosp Infect 1995;30:88-106.

67. Jarvis WR. Handwashing-the Semmelweis lesson forgotten? Lancet 1994;344:1311-1312.

68. Voss A, Widmer AF. No time for handwashing!? Handwashing versus alcoholic rub: can we afford 100\% compliance? Infect Control Hosp Epidemiol 1997;18:205-208.

69. Larson E, McGeer A, Quraishi A, Krenzischek D, Parsons BJ, Holdford $\mathrm{J}$, et al. Effect of an automated sink on handwashing practices and attitudes in high-risk units. Infect Control Hosp Epidemiol 1991;12:422-428.

70. Maki DG, Zilz MA, McCormick R. The effectiveness of using pre-emptive barrier precautions routinely (protective isolation) in all high-risk patients to prevent nosocomial infection with resistant organisms, especially MRSA, VRE, and $C$ difficile. The 34th Annual Meeting of the Infectious Diseases Society of America; New Orleans, LA; September 1996. Abstract 43.

71. Goldmann DA, Weinstein RA, Wenzel RP, Tablan OC, Duma RJ, Gaynes $\mathrm{RP}$, et al. Strategies to prevent and control antimicrobial-resistant microorganisms in hospitals: a challenge to hospital leadership. JAMA 1996;275:234-240.

72. Centers for Disease Control and Prevention. Update: Staphylococcus aureus with reduced susceptibility to vancomycin-United States. MMWR 1997;46:813-815.

\title{
International Course in Applied Epidemiology
}

\section{Gina Pugliese, RN, MS Martin S. Favero, PhD}

The CDC and Emory University will cosponsor a course in applied epidemiology designed for international public health professionals to be held at the CDC on October 5-30, 1998. The course emphasizes the practical application of epidemiol- ogy to public health problems and comprises lectures, workshops, classroom exercises (including actual epidemiological problems), and computer laboratories. Topics covered include descriptive epidemiology and biostatistics, analytic epidemiology, epidemic investigation, public health surveill ance, surveys and sampling, computers and Epi Info software, and discussions of selected prevalent dis- eases. There is a tuition charge.

Applications must be received by August 31, 1998. Additional information and applications are available from Department PSB, Rollins School of Public Health, Emory University, 7th Floor, 1518 Clifton Rd NE, Atlanta, GA 30322; telephone 404727-3485; fax 404-727-4590; or e-mail ogostan@sph.emory.edu. 